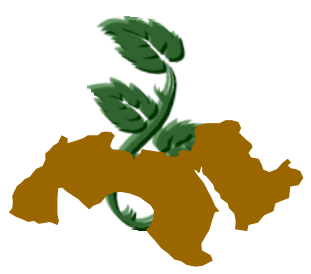

Arab Univ.

J. Agric. Sci.,

Ain Shams Univ.,

Cairo, 19(1), 205-215, 2011

\title{
INFLUENCE OF GREEN-HOUSE COVER ON POTENTIAL EVAPOTRANSPIRATION AND CUCUMBER WATER REQUIREMENTS
}

\author{
Hashem¹, F.A.; M.A. Medany²; E.M. Abd El-Moniem³ \\ and M.M.F. Abdallah ${ }^{4}$ \\ 1- Central Laboratory for Agricultural Climate, Agricultural Research Center, Dokki, Giza- \\ Egypt \\ 2- Horticulture Research Institute, Agricultural Research Center, Giza, Egypt \\ 3- Soil Dept., Fac. Agric., Ain Shams Univ., Cairo, Egypt \\ 4- Horticulture Dept., Fac. Agric., Ain Shams Univ., Cairo, Egypt
}

Keywords: Cucumis sativus L., Irrigation levels, Polyethylene sheet, White net, Black net, Water use efficiency, Crop yield

\section{ABSTRACT}

The experiment was conducted through two successive seasons of 2008 and 2009 at ElBosaily farm, El-Behira governorate at the North Coastal of the Nile Delta, in Egypt. This work aimed to study the effect of three green-house covers (polyethylene sheet, white and black net) and three irrigation levels $[80 \%, 100 \%$ and $120 \%$ of the potential evapotranspiration estimated according to class A pan equation (ETo)], applied by drip irrigation system, on plant growth and crop yield of Cucumber (Cucumis sativus L. Cv. Reda $F_{1}$ ). The experimental design was split- plot with three replicates. The results showed that white net green-house cover optimized growth and yield of cucumber plant. White net cover treatment recorded the highest vegetative growth (plant height, number of leaves, total leaves area, total fresh and dry weights), and significantly increased total yield. The highest vegetative growth was obtained by $100 \% \mathrm{ET}_{\text {o compared to }} 80$ and $120 \% \mathrm{ET}_{\text {o }}$ treatments. The interaction among water treatment and green-house cover indicated the highest vegetative growth and crop yield were obtained under white net cover with $100 \% \mathrm{ET}_{0}$.

\section{INTRODUCTION}

Cucumber is one of the major vegetable crops cultivated in Egypt, under green-house conditions. It is sub-tropical vegetable crop that grows suc- cessfully under conditions of high light, high humidity, high soil moisture, temperature and fertilizers in green-houses (El-Aidy et al 2007). The total number of green-houses in Egypt was estimated to be 22 thousands units of $540 \mathrm{~m}^{2}$ each, according to 2009 statistics; among them, 10 thousands greenhouse were devoted to cucumber cultivated in the spring season, (Anonymous, 2009).

Lorenzo et al (2006) found that green-house shading improved the quality of tomato and increased yield of cucumber, moreover it reduced crop transpiration and thus water uptake, and improved water use efficiency by 47 and $62 \%$ for the tomato and cucumber crops, respectively. Crops grown in open fields of a semi-dry climate were subjected to direct sunlight, high temperatures and wind resulting in high crop evapotranspiration (ETc) therefore, demanding large amounts of water. In contrast, shade-houses favor plant growth since plants are less stressful, direct sunlight was avoided, temperature is lower, humidity is higher, wind speed reduced, and ETc was low. Irrigation water requirement of $23 \%$ to $31 \%$ pan evaporation has been used for plants grown under $70 \%$ light reduction. In addition, water use efficiency increased under shady conditions (Jifon and Syvertsen, 2003). Despite the existence of information about the effect of shading on the productivity of edible horticultural crops (Lorenzo et al 2004), there is little literature is available on shading and its influence as a method to improve water use efficiency.

Water is an important limiting factor in the production and quality of cucumber, because it has a sparse root system, approximately $85 \%$ of the root length is concentrated in the upper $0.3 \mathrm{~m}$ top of 
soil layer (Janoudi and Widders, 1993). One of the most debated issues in irrigation science is estimating $\mathrm{ET}_{0}$ using weather data (Doorenbos and Pruitt, 1997). Irrigation scheduling based on $E T_{0}$ data depends on continual availability of such data. Determination of $E T_{0}$ is needed to support irrigation system design and irrigation scheduling, watershed hydrology studies, process-based crop growth models, and other soil water balance models that attempt to simulate the soil water budget (Donnatlli et al 2006). Halim et al (2003) tested the effect of four irrigation levels $(25,50,75$ and $100 \%$ replenishment of soil water depleted from $0.90 \mathrm{~m}$ soil profile depth) on watermelon yield. They found that the highest yield was obtained from $100 \%$ treatment in comparison with the other treatments. Yesim and Yuksel (2003) studied the yield response of watermelon to different irrigation levels using 25, 50, 75 and $100 \%$ of water requirements, and found that the highest fruit yield was obtained from the plots where irrigation was adequately applied during the total growing season. Water supply was one of the most common limiting environmental factors for plant growth in cucumber (Wang and Zhang, 2004). Deficit water budgets lead to numerous physiological changes, such as altered root to shoot ratio, reduced leaf area or number of leaves, and finally reduced plant growth and yield. Gaafer and Refaie (2006) investigated the effect of different irrigation levels $(80$, 100 , and $120 \%$ of $E T_{0}$ ) on cantaloupe and found that water stress significantly reduced plant growth and total yield.

The main objective of this study was to investigate the impact of green-house cover type and irrigation levels on cucumber plant growth and yield to determine the optimum water requirements under different cover types.

\section{MATERIALS AND METHODS}

The experiment was carried out at the experimental site of protected cultivation of Agricultural Research Center, at El-Bosaily village, El-Behira governorate, located at the North Coast of Egypt through two spring seasons of 2008 and 2009.

\section{Plant materials}

Seeds of cucumber (Cucumis sativus L.cv. Rada F1 hybrid) were sown on January 21, 2008 and January 25, 2009, respectively. Cucumbers were grown under three cover treatments (polyethylene sheet, white net $40 \%$ shade and black net $63 \%$ shade). The width of green-house was $8.5 \mathrm{~m}$, the length was $40 \mathrm{~m}$ and the height was $3.25 \mathrm{~m}$. The green-houses were divided into 5 beds each bed was $1 \mathrm{~m}$ wide and $40 \mathrm{~m}$ long. Common fertilizers application and pests and diseases control were carried out protected cultivation manual (Anonymous, 1996).

\section{Estimation of water requirements}

Evapotranspiration were measured by class $A$ pan under the different green-house covers (class A pan were put to compare with open field). Water requirement under green-house was calculated for the $100 \%$ of $E T_{0}$ according to Hashem (2007), while other treatments $\left(80 \%\right.$ and $120 \%$ of $\left.E T_{0}\right)$ were derived from $100 \%$ of $\mathrm{ET}_{\text {。 }}$ (Table 1). Leaching requirements of $20 \%$ were added to modify different water requirements of 80,100 and $120 \%$ of $\mathrm{ET}_{\mathrm{o}}$. Water valve and Water flow-meter were installed on each plot for each irrigation treatment.

\section{Treatments}

The interaction of three green-house cover treatments (polyethylene sheet, white net $40 \%$ shade and black net $63 \%$ shade) with of three irrigation levels namely $80 \%, 100 \%$ and $120 \%$ of $\mathrm{ET}_{\text {。 }}$ were applied.

\section{Statistical design}

Statistics method of split-plot design was used with three green-house covers as main factor and three irrigation levels as sub-main factor in three replicates. Duncan test was statistically analyzed according to Snedecor and Cochran (1981).

\section{Measurements}

Maximum and minimum air temperature and relative humidity were recorded continuously by using a digital thermo-hygrometer in the middle part of each of the three green-houses, as well as in open field. Air temperature was measured daily at noontime. Plant length $(\mathrm{cm})$, number of leaves and total leaf area $\left(\mathrm{cm}^{2}\right)$ were measured after 85 days form transplanting date. Fruits of cucumber were harvested and total fruit yield was measured during all the season. The water use efficiency (WUE) was calculated according to FAO (1982) as follows: The ratio of crop yield $(Y)$ to the total amount of irrigation water use in the field for the growth season (IR); WUE $\left(\mathrm{Kg} / \mathrm{m}^{3}\right)=\mathbf{Y}(\mathbf{k g}) / \mathbf{I R}$ $\left(\mathrm{m}^{3}\right)$. 
Table 1. Water requirements of cucumber under different green-house covers during spring seasons of 2008 and 2009

\begin{tabular}{|c|c|c|c|c|c|c|}
\hline \multirow{2}{*}{ Week } & \multicolumn{7}{|c|}{ 2008 season } & \multicolumn{3}{c|}{ 2009 season } \\
\cline { 2 - 7 } & Polyethylene & White net & Black net & Polyethylene & White net & Black net \\
\hline week1 & 0.25 & 0.23 & 0.19 & 0.24 & 0.22 & 0.19 \\
\hline week2 & 0.30 & 0.28 & 0.23 & 0.27 & 0.26 & 0.21 \\
\hline week 3 & 0.36 & 0.33 & 0.35 & 0.36 & 0.32 & 0.36 \\
\hline week 4 & 0.43 & 0.41 & 0.42 & 0.44 & 0.39 & 0.43 \\
\hline week 5 & 0.47 & 0.44 & 0.43 & 0.47 & 0.39 & 0.38 \\
\hline week 6 & 0.65 & 0.59 & 0.47 & 0.62 & 0.57 & 0.47 \\
\hline week 7 & 1.02 & 0.93 & 0.74 & 0.98 & 0.94 & 0.71 \\
\hline week 8 & 1.27 & 1.14 & 0.89 & 1.20 & 1.02 & 0.90 \\
\hline week 9 & 1.58 & 1.45 & 1.05 & 1.56 & 1.38 & 1.07 \\
\hline week 10 & 1.66 & 1.24 & 1.38 & 1.47 & 1.26 & 1.23 \\
\hline week 11 & 1.53 & 1.31 & 1.20 & 1.55 & 1.24 & 1.14 \\
\hline week 12 & 1.52 & 1.42 & 1.14 & 1.44 & 1.37 & 1.09 \\
\hline week 13 & 1.55 & 1.46 & 1.18 & 1.49 & 1.48 & 1.17 \\
\hline week 14 & 1.60 & 1.42 & 1.24 & 1.42 & 1.35 & 1.18 \\
\hline week 15 & 1.58 & 1.38 & 1.19 & 1.50 & 1.40 & 1.20 \\
\hline week 16 & 1.58 & 1.49 & 1.30 & 1.56 & 1.32 & 1.24 \\
\hline week 17 & 1.50 & 1.42 & 1.34 & 1.52 & 1.43 & 1.27 \\
\hline week 18 & 1.52 & 1.40 & 1.32 & 1.51 & 1.34 & 1.31 \\
\hline
\end{tabular}

\section{Soil analysis}

Soil samples analysis for the experimental site were performed, before planting (Table, 2). Physical and chemical properties of soil were described by Piper (1950), Jackson (1967) and Black (1969).

\section{Chemical analysis}

Chemical analysis of cucumber plant leaves, grown under different covers and irrigation levels were done by estimating total nitrogen, phosphorus and potassium. The fourth leaf of cucumber plants were dried and digested in the sulphuric acid and hydrogen peroxide mixture according to the method described by Allen (1974). Total nitrogen was determined by Kjeldahl method according to the procedure described by FAO (1980). Phosphorus content was determined using spectrophotometer according to Watanabe and Olsen (1965).
Potassium content was determined photometrically using Flame photometer as described by Chapman and Pratt (1961).

\section{RESULTS AND DISCUSSION}

Effect of different green-house covers on climatic data

The application of different green-house covers of the polyethylene sheet cover, black net and white net, green-house showed that, the use of nets exerted an influence on temperature (Fig. 1). Air temperatures tended to be lower under the black net comparing with other covers, due to the interception of radiation which is greater than the gain of temperature caused by the use of nets due to their role in the interception of air circulation. Higher differences were recorded in the growing seasons. Evapotranspiration under all covers tended to be lower than open field sheet cover by 
Table 2. Physical and chemical analysis of soil plots at El-Bosaily experimental site before cultivation

\begin{tabular}{|c|c|c|c|c|c|c|c|}
\hline \multicolumn{7}{|c|}{ Physical analysis } \\
\cline { 1 - 2 } Sand & Silt & Clay & Texture Class & F.C & W.P & O.M & \multirow{2}{*}{$\begin{array}{c}\text { Bulk density } \\
\text { g/cm }\end{array}$} \\
\cline { 2 - 6 } & $\%$ & \multicolumn{3}{|c|}{$\%$} & 1.21 \\
\hline 41 & 40.6 & 18.4 & Loamy & 17 & 8 & 0.3 & 1.3 \\
\hline
\end{tabular}

\begin{tabular}{|c|c|c|c|c|c|c|c|c|c|}
\hline \multicolumn{10}{|c|}{ Chemical analysis } \\
\hline \multirow[t]{2}{*}{$\mathrm{pH}$} & \multirow{2}{*}{$\begin{array}{c}E C_{e} \\
d S / m\end{array}$} & $\mathrm{Ca}^{++}$ & $\mathbf{M g}^{++}$ & $\mathrm{Na}^{+}$ & $\mathrm{K}^{+}$ & $\mathrm{CO}_{3}^{--}$ & $\mathrm{HCO}_{3}^{-}$ & $\mathrm{Cl}^{-}$ & $\mathrm{SO}_{4}^{--}$ \\
\hline & & \multicolumn{8}{|c|}{ meq/L } \\
\hline 7.75 & 1.25 & 2.8 & 2.15 & 6.69 & 0.9 & - & 1.9 & 4.5 & 6.14 \\
\hline
\end{tabular}

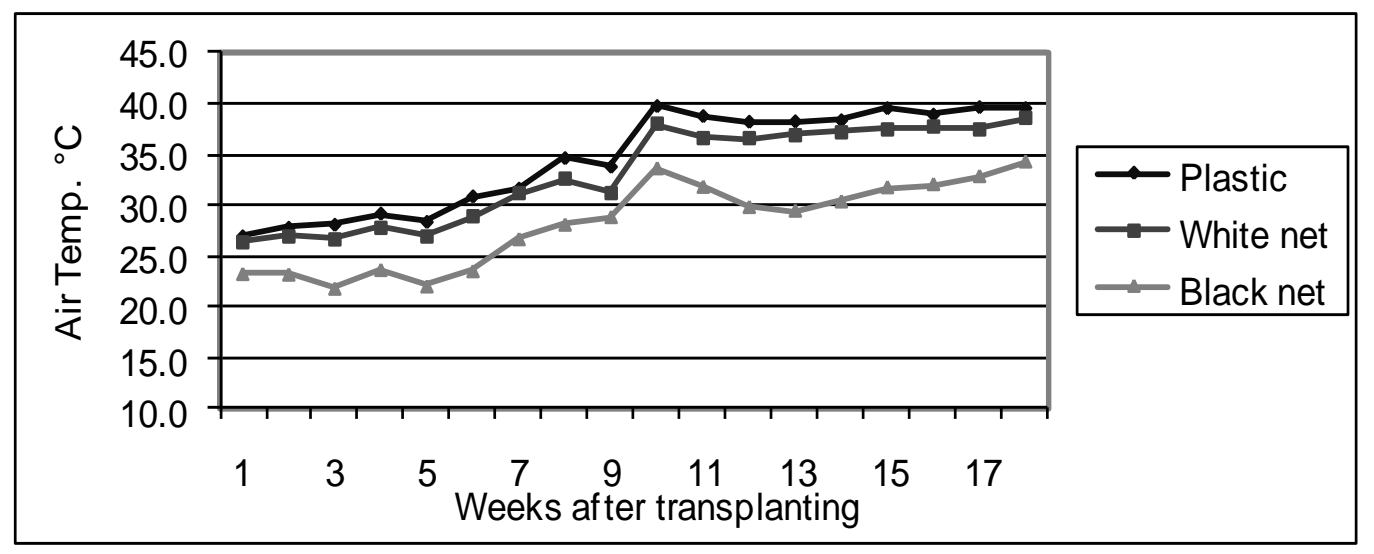

Fig. 1. The average means air temperatures under polyethylene sheet, black net and white net of two spring seasons 2008 and 2009

$2.0-2.5 \mathrm{ET}_{0}$ (Fig. 2) because of the green-house effect and the low radiation under these covers. Polyethylene sheet cover obtained the highest air temperatures and open filed recorded the highest evapotranspiration during the whole season, which agreed with the results reported by Abdrabbo (2001) and Salman et al (1992). Saleh and Ozawa (2006) found a moderate decrease in temperatures associated with the use of nets at the spring season.

Average relative humidity increased by the use of polyethylene sheet cover by $4-8 \%$ as compared with black net (Fig. 3). These results were in line with those reported by Iglesias and Alegre, (2006), indicating a 3 - 9\% increase in humidity associated with the use of nets. These authors also reported a decrease in evaporation associated with the use of nets and a significant reduction in wind speed. Campen and Bot (2003) pointed out that pressure difference over the openings was one of the driving forces for ventilation, which could be either due to the wind outside the greenhouse or due to the temperature difference over the openings.

Effect of different green-house covers and irrigation levels treatments on vegetative growth of cucumber plants

Data in Table (3) indicate that there are significant differences in vegetative parameters i.e. plant height, number of leaves, leaf area, total fresh and dry weight of cucumber plants grown under different green-house covers and irrigation levels. Vegetative growth under white net was significantly higher than that under polyethylene sheet cover in both seasons; the lowest vegetative parameters were obtained under black net cover conditions. 


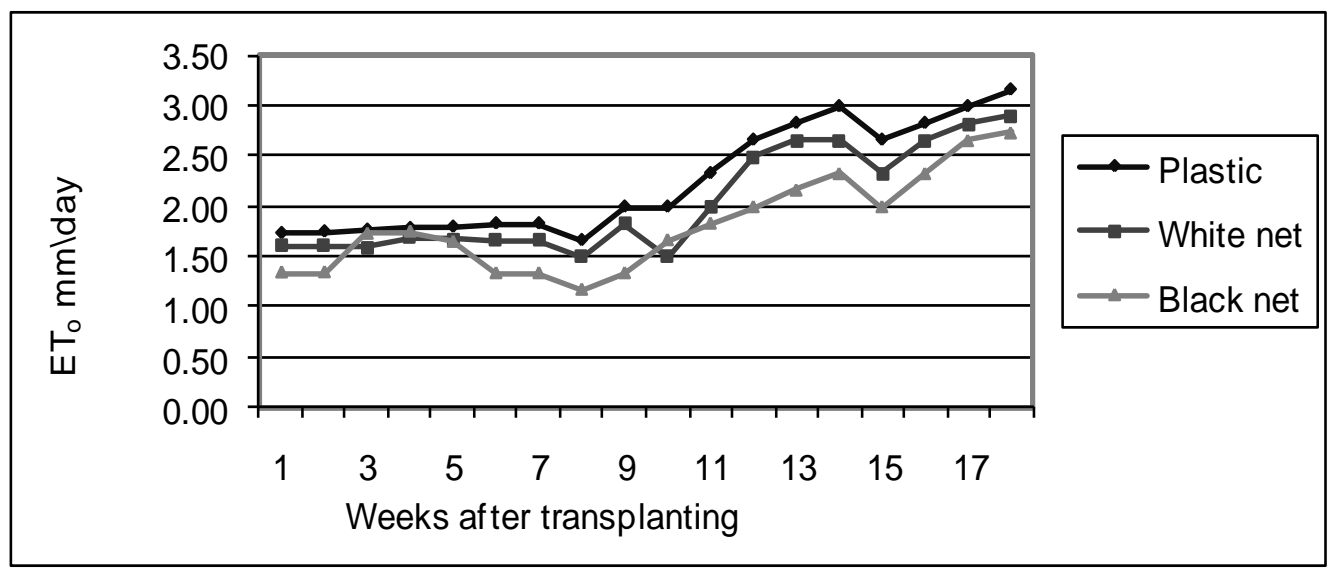

Fig. 2. The average of evapotranspiration under polyethylene sheet, black net and white net of two spring seasons 2008 and 2009

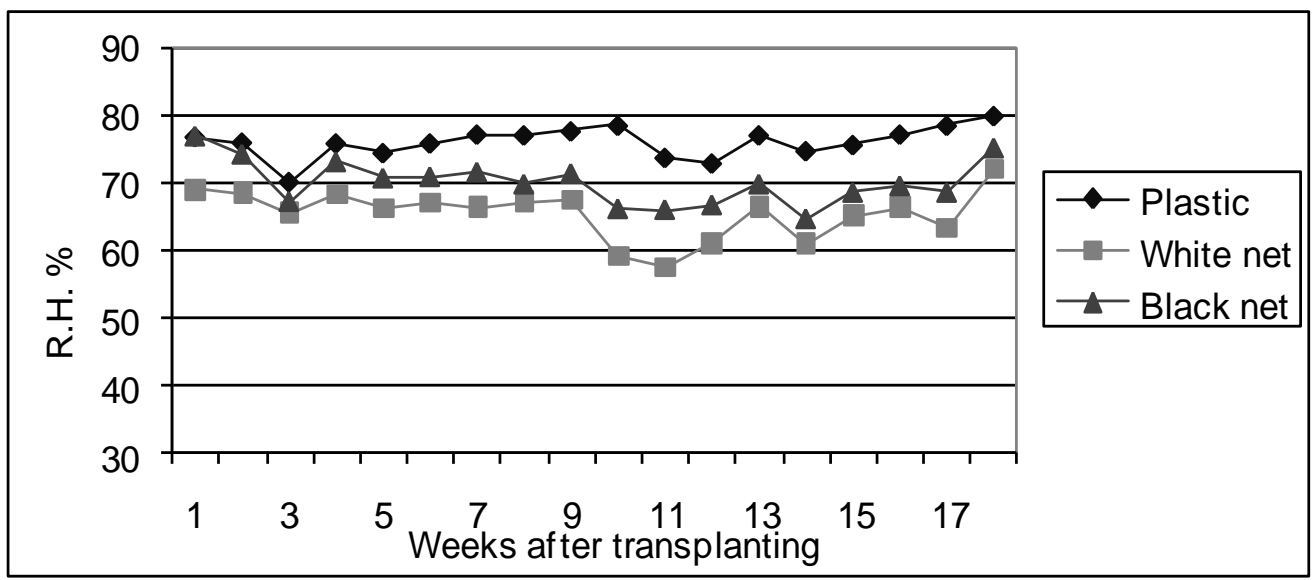

Fig. 3. The average of relative humidity under polyethylene sheet, black net and white net of two spring seasons 2008 and 2009

Generally, the results indicated that vegetative parameters increased with the irrigation level $100 \% \mathrm{ET}_{0}$ followed by $80 \%$ and $120 \%$ irrigation levels in both seasons. High irrigation level (120\% $\left.E T_{0}\right)$ recorded the lowest vegetative parameters, Regarding the effect of interaction between greenhouse cover and irrigation levels forms on vegetative parameters, the combination between greenhouse cover and irrigation level showed that the highest significant value was for $100 \%$ irrigation levels, with significant difference between greenhouse covers, while the lowest value was obtained by $120 \%$ irrigation level under black net conditions in both seasons.

The improved vegetative growth evidenced as plant height, number of leaves, and total leaf area per plant under the different green-house shade levels may be due to the favorable weather conditions, i.e., increase in relative humidity, lower and maximum temperature, light irradiance and finally lower wind speed in comparison with open field conditions (Iglesias and Alegre, 2006). The results of the present study are in agreement with Lorenzo et al (2006) who found that vegetative growth of the cucumber plants under shade net cover was higher than that obtained under other treatment. Other possibility was increasing the plant uptake ability to water and nutrients which ultimately accelerated the rate of vegetative growth under green-house conditions (Marouelli and Silva, 2005). Increasing vegetative characteristics under $100 \%$ ET。 irrigation levels could be attributed to the suitable irrigation quantity especially in the early stage of crop growth which enhanced a deeper and more extensive root system as mentioned by Ngouajio et al 2007. Bonanno and Mack (1983) found that leaf turgor potential levels of plants grown in low water treatments were gen- 
erally lower compared to those grown under high water levels, so that, the decrease in turgor due to the decrease of plant growth (leaf area and total fresh weight).

\section{Effect of different green-house covers and irri- gation levels treatments on yield production of cucumber plants}

The highest early fruit yields were recorded by polyethylene sheet treatment with $120 \%$ of irrigation levels. As for total fruit yields per plant under different green-house cover and irrigation levels showed that the lowest values with black net in the two studied seasons (Table 4). Meanwhile, white net gave the highest significantly total yield. The highest significant yield was obtained with $100 \%$ applied irrigation levels, followed by $80 \%$ and $120 \%$ irrigation relative to those grown at the other treatments. The interaction effect between the different green-house covers and irrigation level revealed that the highest fruit weight was obtained by white net cover combined with $100 \% \mathrm{ET}_{0}$ followed by polyethylene sheet cover combined with $80 \% \mathrm{ET}_{\mathrm{o}}$. The lowest fruit weight was obtained by the black net conditions combined with $120 \% E T_{0}$, these results are supported by El-Gizawy, et al (1992). Also, El-Nemr et al 2006 found that increasing shade density in the spring season increased vegetative growth of plants under open field conditions while decreased fruit weight and number of fruits due to less photosynthesis associated with less radiation under shaded plants. Furthermore, the reduction of radiation is responsible for down-regulation of photosynthetic capacity of leaves and consequently a lower light saturated photosynthetic rate compared to the control (Abdrabbo et al 2009). These results might be due to adequate moisture availability in the soil which might have increased various physiological processes, better plant nutrient uptake, higher rates of photosynthesis, which might reflected on more number of fruits and higher fruit weight (Ngouajio et al 2007).

Effect of different green-house covers and irrigation levels treatments on plant chemical composition

Data presented in Table (5) showed that, the type of green-house cover and irrigation treatment significantly affected the NPK percentage in cucumber fourth leaf, during the two growing seasons. Green-house covers significantly affected the NPK percentages. White net produced the highest average values of NPK percentages of cucumber fourth leaf, followed by polyethylene sheet cover treatment. The lowest NPK percentages were obtained in forth leaf by the black net treatment during the two seasons. The $80 \% \mathrm{ET}_{\text {o }}$ increased the percentages of NPK followed by $100 \% \mathrm{ET}_{\mathrm{o}}$, while the lowest NPK contents were obtained by $120 \% \mathrm{ET}_{0}$. Increasing the percentage of NPK by $80 \% \mathrm{ET}_{\text {。 }}$ may be due to the good soil water content under $80 \% \mathrm{ET}_{\text {o treatment (Saleh }}$ and Ozawa, 2006). Regarding the interaction effect between green-house cover and irrigation, the highest NPK contents were obtained by $80 \% \mathrm{ET}$ 。 combined with white net cover followed by $100 \%$ $E T$ o with white net cover. Increased yield could be largely attributed to proper soil temperature due to application of the green-house cover, which was resulted in enhancement of soil environment around roots of cucumber, which led to increasing plant growth, and hence increasing nutrient absorption and uptake. These results are in agreement with those obtained by Fonsecal et al (2003). Optimal root zone temperature conditions allow for adequate root function including proper uptake of water and nutrients (El-Shinawy, 1997). Using proper water quantity application allows plants to use water and nutrients from deep soil, thus increases water, nutrients use efficiency and reduce nitrogen leaching. Excess irrigation not only reduces crop yield, but also increases nutrient leaching (Zegbe-Dominguez et al 2006). On the other hand, this decrease in nutrient concentration of a plant tissue under high irrigation level was observed due to two reasons, the first is due to dilution effect (increase plant biomass at a constant nutrient stock) and second is nutrient movements toward fruits or other plant organs include cucumber yield (Cantliffe, 1977), tomato (Clough et al 1992) and cucumber and melon (Nerson et al 1997).

Effect of different green-house covers and irrigation levels treatments on water use efficiency (WUE)

Data in Table (6) show the effect of different green-house cover treatments on WUE. Using white net, increased WUE during the two growing seasons. The increase of irrigation quantity over

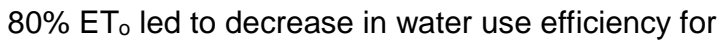
all irrigation treatments, while the highest WUE was obtained by $80 \% \mathrm{ET}_{\mathrm{o}}$. the interaction between green-house cover and irrigation treatment for 
Table 3. Effect of different green-house covers and irrigation levels on vegetative growth characters of cucumber plants during the two spring seasons 2008 and 2009

\begin{tabular}{|c|c|c|c|c|c|c|c|c|}
\hline & \multicolumn{4}{|c|}{2008 season } & \multicolumn{4}{|c|}{2009 season } \\
\hline & & Irrigation & evels (B) & & & Irrigatio & evels (B) & \\
\hline \multirow{2}{*}{$\begin{array}{c}\text { Green-house } \\
\text { cover(A) }\end{array}$} & $80 \%$ & $100 \%$ & $120 \%$ & $\begin{array}{c}\text { Mean } \\
(\mathrm{A})\end{array}$ & $80 \%$ & $100 \%$ & $120 \%$ & $\begin{array}{c}\text { Mean } \\
(\mathrm{A}) \\
\end{array}$ \\
\hline & \multicolumn{3}{|c|}{ Plant height (cm) } & & \multicolumn{3}{|c|}{ Plant height (cm) } & \\
\hline White net & $226.2 \mathrm{~b}$ & $245.1 \mathrm{a}$ & $224.4 \mathrm{~b}$ & $231.9 \mathrm{~A}$ & $226 \mathrm{~b}$ & $233 \mathrm{a}$ & 222 c & $227 \mathrm{~A}$ \\
\hline Polyethylene & $209.0 \mathrm{~cd}$ & $210.1 \mathrm{c}$ & $206.3 d$ & 208.5 B & $206 d$ & 202 e & 203 e & 204 B \\
\hline Black net & $188.4 \mathrm{e}$ & $190.8 \mathrm{e}$ & $183.2 \mathrm{f}$ & $187.5 \mathrm{C}$ & $181 \mathrm{~g}$ & $189 \mathrm{f}$ & $183 \mathrm{~g}$ & $184 \mathrm{C}$ \\
\hline \multirow[t]{2}{*}{ Mean $(\mathrm{B})$} & $207.9 \mathrm{~B}$ & $215.3 \mathrm{~A}$ & $204.6 \mathrm{C}$ & & $205 B$ & $208 \mathrm{~A}$ & $203 \mathrm{C}$ & \\
\hline & \multicolumn{3}{|c|}{ Number of leaves } & & \multicolumn{3}{|c|}{ Number of leaves } & \\
\hline White net & $35.06 \mathrm{~b}$ & $37.05 \mathrm{a}$ & $32.30 \mathrm{c}$ & $34.80 \mathrm{~A}$ & $34.7 \mathrm{~b}$ & $35.3 a b$ & $31.9 \mathrm{c}$ & $34.0 \mathrm{~A}$ \\
\hline Polyethylene & $34.99 \mathrm{~b}$ & $37.52 \mathrm{a}$ & $28.01 \mathrm{e}$ & $33.51 \mathrm{~B}$ & $34.2 \mathrm{~b}$ & $36.1 \mathrm{a}$ & $27.5 \mathrm{e}$ & $32.6 \mathrm{~B}$ \\
\hline Black net & $27.69 \mathrm{e}$ & $30.85 d$ & $27.28 \mathrm{e}$ & $28.61 \mathrm{C}$ & $26.3 \mathrm{e}$ & $30.6 \mathrm{~d}$ & $27.2 \mathrm{e}$ & $28.0 \mathrm{C}$ \\
\hline \multirow[t]{2}{*}{ Mean (B) } & $32.58 \mathrm{~B}$ & $35.14 \mathrm{~A}$ & $29.20 \mathrm{C}$ & & $31.8 \mathrm{~B}$ & $34.0 \mathrm{~A}$ & $28.9 \mathrm{C}$ & \\
\hline & \multicolumn{3}{|c|}{ Total leaf area $\left(\mathrm{cm}^{2}\right)$} & & \multicolumn{3}{|c|}{ Total leaf area $\left(\mathrm{cm}^{2}\right)$} & \\
\hline White net & 8476 b & 8891 a & $8420 \mathrm{c}$ & $8596 \mathrm{~A}$ & $8402 a b$ & 8449 a & $8317 a b$ & $8389 \mathrm{~A}$ \\
\hline Polyethylene & $8260 d$ & 8188 e & $7878 f$ & 8108 B & 8084 b & 7865 c & 7729 c & $7893 \mathrm{~B}$ \\
\hline Black net & $7839 \mathrm{f}$ & $8231 d$ & $7486 \mathrm{~g}$ & $7852 \mathrm{C}$ & $7464 d$ & $8151 b$ & $7470 \mathrm{~d}$ & $7695 \mathrm{C}$ \\
\hline \multirow[t]{2}{*}{ Mean $(B)$} & 8192 B & $8436 \mathrm{~A}$ & $7928 \mathrm{C}$ & & 7983 B & $8155 \mathrm{~A}$ & $7839 \mathrm{C}$ & \\
\hline & \multicolumn{3}{|c|}{ Total fresh weight(g/plant) } & & \multicolumn{3}{|c|}{ Total fresh weight(g/plant) } & \\
\hline White net & $325.7 \mathrm{~b}$ & $334.8 \mathrm{a}$ & $297.8 d$ & $319.4 \mathrm{~A}$ & $322.5 \mathrm{a}$ & $319.8 \mathrm{a}$ & 294.7 b & $312.3 \mathrm{~A}$ \\
\hline Polyethylene & $289.2 f$ & $307.3 \mathrm{c}$ & $262.2 \mathrm{~g}$ & $286.2 \mathrm{~B}$ & $283.0 \mathrm{~d}$ & $294.7 b$ & $256.5 \mathrm{e}$ & $278.1 \mathrm{~B}$ \\
\hline Black net & $251.2 \mathrm{~h}$ & $294.3 \mathrm{e}$ & $228.7 \mathrm{i}$ & $258.1 \mathrm{C}$ & $239.4 f$ & $291.2 \mathrm{c}$ & $228.3 \mathrm{~g}$ & $252.9 \mathrm{C}$ \\
\hline \multirow[t]{2}{*}{ Mean $(B)$} & $288.7 \mathrm{~B}$ & $312.1 \mathrm{~A}$ & $262.9 \mathrm{C}$ & & $281.6 \mathrm{~B}$ & $301.9 \mathrm{~A}$ & $259.8 \mathrm{C}$ & \\
\hline & \multicolumn{3}{|c|}{ Total dry weight(g/plant) } & & \multicolumn{3}{|c|}{ Total dry weight(g/plant) } & \\
\hline White net & $49.84 \mathrm{c}$ & $50.36 \mathrm{~b}$ & $54.71 \mathrm{a}$ & $51.64 \mathrm{~A}$ & $48.0 \mathrm{c}$ & $49.5 \mathrm{~b}$ & $55.5 \mathrm{a}$ & $51.0 \mathrm{~A}$ \\
\hline Polyethylene & $44.05 \mathrm{e}$ & $46.68 d$ & $41.71 \mathrm{~g}$ & $44.15 \mathrm{~B}$ & $43.0 \mathrm{f}$ & $44.8 d$ & $41.7 \mathrm{~g}$ & $43.2 \mathrm{~B}$ \\
\hline Black net & $42.17 \mathrm{f}$ & $44.07 \mathrm{e}$ & $34.22 \mathrm{~h}$ & $40.16 \mathrm{C}$ & $41.8 \mathrm{~g}$ & $43.5 \mathrm{e}$ & $33.7 \mathrm{C}$ & $39.7 \mathrm{~h}$ \\
\hline Mean (B) & $45.36 \mathrm{~B}$ & $47.04 \mathrm{~A}$ & $43.55 \mathrm{C}$ & & $44.3 \mathrm{~B}$ & $45.9 \mathrm{~A}$ & $43.6 \mathrm{C}$ & \\
\hline
\end{tabular}

Means followed by the same letter within column are not significantly different $(P<0.05)$ 
Table 4. Effect of different green-house covers and irrigation levels on early and total fruit weight of cucumber plants during the two spring seasons 2008 and 2009

\begin{tabular}{|c|c|c|c|c|c|c|c|c|}
\hline & \multicolumn{4}{|c|}{2008 season } & \multicolumn{4}{|c|}{2009 season } \\
\hline & \multicolumn{4}{|c|}{ Irrigation levels (B) } & \multicolumn{4}{|c|}{ Irrigation levels (B) } \\
\hline \multirow{2}{*}{$\begin{array}{l}\text { Green-house } \\
\text { cover(A) }\end{array}$} & $80 \%$ & $100 \%$ & $120 \%$ & $\begin{array}{c}\text { Mean } \\
\text { (A) }\end{array}$ & $80 \%$ & $100 \%$ & $120 \%$ & $\begin{array}{l}\text { Mean } \\
\text { (A) }\end{array}$ \\
\hline & \multicolumn{3}{|c|}{ Early yield(g/plant) } & & \multicolumn{3}{|c|}{ Early yield(g/plant) } & \\
\hline White net & 473 e & $554 \mathrm{c}$ & $671 \mathrm{a}$ & $566 \mathrm{~B}$ & $468.9 \mathrm{~d}$ & $527.9 \mathrm{c}$ & $662.7 \mathrm{a}$ & $553.2 \mathrm{~B}$ \\
\hline Polyethylene & $510 d$ & $595 \mathrm{~b}$ & $679 a$ & $595 \mathrm{~A}$ & $499.2 \mathrm{~cd}$ & $571.7 \mathrm{~b}$ & $667.7 \mathrm{a}$ & $579.6 \mathrm{~A}$ \\
\hline Black net & $299 \mathrm{~h}$ & $367 \mathrm{~g}$ & $406 f$ & $358 \mathrm{C}$ & $285.2 \mathrm{~g}$ & $363.6 \mathrm{f}$ & $405.6 \mathrm{e}$ & $351.4 \mathrm{C}$ \\
\hline \multirow[t]{2}{*}{ Mean $(B)$} & $428 \mathrm{C}$ & 505 B & $585 \mathrm{~A}$ & & $417.8 \mathrm{C}$ & $487.7 \mathrm{~B}$ & $578.6 \mathrm{~A}$ & \\
\hline & \multicolumn{3}{|c|}{ Total yield(g/plant) } & & \multicolumn{3}{|c|}{ Total yield(g/plant) } & (A) \\
\hline White net & $3164 \mathrm{c}$ & 3506 a & $2947 d$ & $3206 \mathrm{~A}$ & $3263 \mathrm{a}$ & 3312 a & 2940 c & $3172 \mathrm{~A}$ \\
\hline Polyethylene & $2977 d$ & $3271 p$ & $2509 f$ & 2919 B & 2902 c & $3133 b$ & 2448 e & 2827 B \\
\hline Black net & $2503 f$ & 2704 e & $2178 \mathrm{~g}$ & 2462 C & 2373 e & $2771 d$ & $2151 \mathrm{f}$ & $2431 \mathrm{C}$ \\
\hline Mean (B) & $2881 \mathrm{~B}$ & $3160 \mathrm{~A}$ & $2545 \mathrm{C}$ & & 2846 B & $3072 \mathrm{~A}$ & $2513 \mathrm{C}$ & \\
\hline
\end{tabular}

Means followed by the same letter within column are not significantly different $(P<0.05)$

Table 5. Effect of different green-house covers and irrigation levels on the NPK percentage of cucumber fourth leaf during the two spring seasons 2008 and 2009

\begin{tabular}{|c|c|c|c|c|c|c|c|c|}
\hline & \multicolumn{4}{|c|}{2008 season } & \multicolumn{4}{|c|}{2009 season } \\
\hline & \multicolumn{4}{|c|}{ Irrigation levels (B) } & \multicolumn{4}{|c|}{ Irrigation levels (B) } \\
\hline \multirow{2}{*}{$\begin{array}{c}\text { Green-house } \\
\text { Cover(A) }\end{array}$} & $80 \%$ & $100 \%$ & $120 \%$ & Mean & $80 \%$ & $100 \%$ & $120 \%$ & Mean \\
\hline & \multicolumn{3}{|c|}{$\mathbf{N} \%$} & (A) & \multicolumn{3}{|c|}{$\mathbf{N} \%$} & (A) \\
\hline White net & $3.37 \mathrm{a}$ & $3.03 \mathrm{~d}$ & $2.43 \mathrm{~g}$ & $2.95 \mathrm{~A}$ & $3.34 \mathrm{a}$ & $2.89 \mathrm{~d}$ & $2.40 \mathrm{~g}$ & $2.88 \mathrm{~A}$ \\
\hline Polyethylene & $3.20 \mathrm{~b}$ & $2.86 \mathrm{e}$ & $2.29 \mathrm{~h}$ & $2.79 \mathrm{~B}$ & $3.13 \mathrm{~b}$ & $2.75 f$ & $2.25 \mathrm{~h}$ & $2.71 \mathrm{~B}$ \\
\hline Black net & $3.09 \mathrm{~d}$ & $2.73 \mathrm{f}$ & $2.18 \mathrm{i}$ & $2.67 \mathrm{C}$ & $2.94 \mathrm{c}$ & $2.70 \mathrm{f}$ & $2.18 \mathrm{i}$ & $2.60 \mathrm{C}$ \\
\hline Mean (B) & $3.22 \mathrm{~A}$ & $2.87 \mathrm{~B}$ & $2.30 \mathrm{C}$ & & $3.14 \mathrm{~A}$ & $2.78 \mathrm{~B}$ & $2.28 \mathrm{C}$ & \\
\hline & \multicolumn{4}{|c|}{$\mathbf{P} \%$} & \multicolumn{4}{|c|}{$\mathbf{P} \%$} \\
\hline White net & $0.65 \mathrm{a}$ & $0.58 \mathrm{c}$ & $0.55 d$ & $0.59 \mathrm{~A}$ & $0.62 \mathrm{a}$ & $0.57 c$ & $0.55 \mathrm{~d}$ & $0.58 \mathrm{~A}$ \\
\hline Polyethylene & $0.60 \mathrm{~b}$ & $0.53 \mathrm{e}$ & $0.51 \mathrm{f}$ & $0.55 \mathrm{~B}$ & $0.59 \mathrm{~b}$ & $0.51 \mathrm{e}$ & $0.51 \mathrm{e}$ & $0.54 \mathrm{~B}$ \\
\hline Black net & $0.51 \mathrm{f}$ & $0.47 \mathrm{~g}$ & $0.45 \mathrm{~h}$ & $0.48 \mathrm{C}$ & $0.51 \mathrm{e}$ & $0.47 f$ & $0.45 \mathrm{~g}$ & $0.47 \mathrm{C}$ \\
\hline \multirow[t]{2}{*}{ Mean (B) } & $0.59 \mathrm{~A}$ & $0.53 \mathrm{~B}$ & $0.50 \mathrm{C}$ & & $0.57 \mathrm{~A}$ & $0.52 \mathrm{~B}$ & $0.50 \mathrm{C}$ & \\
\hline & \multicolumn{3}{|c|}{ K \% } & & \multicolumn{4}{|c|}{$\mathrm{K} \%$} \\
\hline White net & $2.79 \mathrm{~d}$ & $3.07 \mathrm{a}$ & $3.03 \mathrm{~b}$ & $2.96 \mathrm{~A}$ & $2.88 \mathrm{~b}$ & $2.91 \mathrm{~b}$ & $3.03 \mathrm{a}$ & $2.94 \mathrm{~A}$ \\
\hline Polyethylene & $3.06 a b$ & $2.6 \mathrm{e}$ & $2.34 \mathrm{f}$ & $2.69 \mathrm{~B}$ & $2.98 \mathrm{a}$ & $2.56 \mathrm{~d}$ & 2.28 ef & $2.61 \mathrm{~B}$ \\
\hline Black net & $2.86 \mathrm{c}$ & $2.23 \mathrm{~g}$ & $2.10 \mathrm{~h}$ & $2.40 \mathrm{C}$ & $2.72 \mathrm{c}$ & $2.29 \mathrm{e}$ & $2.08 \mathrm{f}$ & $2.36 \mathrm{C}$ \\
\hline Mean (B) & $2.90 \mathrm{~A}$ & $2.66 \mathrm{~B}$ & $2.49 \mathrm{C}$ & & $2.86 \mathrm{~A}$ & $2.59 \mathrm{~B}$ & $2.46 \mathrm{C}$ & \\
\hline
\end{tabular}

Means followed by the same letter within column are not significantly different $(P<0.05)$ 
Table 6. Effect of different green-house covers and irrigation levels on water use efficiency (WUE) of cucumber plant during the two spring seasons 2008 and 2009

\begin{tabular}{|c|c|c|c|c|c|c|c|c|}
\hline & \multicolumn{4}{|c|}{2008 season } & \multicolumn{4}{|c|}{2009 season } \\
\hline & \multicolumn{4}{|c|}{ Irrigation levels (B) } & \multicolumn{4}{|c|}{ Irrigation levels (B) } \\
\hline \multirow{2}{*}{$\begin{array}{l}\text { Green-house } \\
\text { cover(A) }\end{array}$} & $80 \%$ & $100 \%$ & $120 \%$ & Mean (A) & $80 \%$ & $100 \%$ & $120 \%$ & $\operatorname{Mean}(\mathrm{A})$ \\
\hline & \multicolumn{3}{|c|}{$\begin{array}{l}\text { water use efficiency } \\
(\mathrm{Kg} / \mathrm{m} 3)\end{array}$} & & \multicolumn{3}{|c|}{$\begin{array}{l}\text { water use efficiency } \\
(\mathrm{Kg} / \mathrm{m} 3)\end{array}$} & \\
\hline White net & $30.8 \mathrm{a}$ & $27.3 \mathrm{~b}$ & $19.1 \mathrm{f}$ & $25.8 \mathrm{~A}$ & $33.0 \mathrm{a}$ & $26.8 \mathrm{~b}$ & 19.8 e & $26.5 \mathrm{~A}$ \\
\hline Polyethylene & $26.1 \mathrm{c}$ & 22.9 e & $14.7 \mathrm{~h}$ & $21.2 \mathrm{C}$ & $26.4 \mathrm{~b}$ & $22.8 d$ & $14.9 \mathrm{~g}$ & $21.4 \mathrm{C}$ \\
\hline Black net & $27.8 \mathrm{~b}$ & $24.0 \mathrm{~d}$ & $16.1 \mathrm{~g}$ & $22.7 \mathrm{~B}$ & $27.3 \mathrm{~b}$ & $25.5 \mathrm{c}$ & $16.5 f$ & $23.1 \mathrm{~B}$ \\
\hline Mean (B) & $28.2 \mathrm{~A}$ & $24.8 \mathrm{~B}$ & $16.6 \mathrm{C}$ & & $28.9 \mathrm{~A}$ & $25.0 \mathrm{~B}$ & $17.0 \mathrm{C}$ & \\
\hline
\end{tabular}

Means followed by the same letter within column are not significantly different $(\mathrm{P}<0.05)$

WUE was significant. The highest WUE was obtained by white net treatment combined with $80 \%$ $E T_{0}$. The level of $120 \% E_{0}$ o combined with black net treatment had the lowest WUE during the two studied seasons. These results were in agreement with those obtained by El-Shinawy, 1997 and Abdrabbo et al (2009).

\section{Conclusion}

In conclusion, the results of the present study demonstrate that the growth characters (plant height, total leaf area, total fresh weight and total dry weight) and fruit yield were increased by using white net cover throughout the growing season, which stimulated and encouraged cucumber plant growth. Optimum water requirements had the highest plant growth characters and yield. However, using black net cover fruit yield was decreased compared with other treatments. This study recommended the use of $100 \% \mathrm{ET}_{\text {。 }}$ from measured evapotranspiration with white net to grow the cucumber during the Spring season.

\section{REFERENCES}

Abdrabbo, M.A.A. (2001). Effect of Shading on Cucumber Productivity under GreenHouses. p. 86. M.Sc. Thesis, Ain Shams University, Cairo Egypt.

Abdrabbo, M.A.A.; A.A. Farag and M.K. Hassanein. (2009). Irrigation requirements for cucumber under different mulch colors. Egypt. J. Hort. 36: 333-346.

Allen, S.E. (1974). Chemical Analysis of Ecological Materials. p. 565. Black-Well, Oxford,

Anonymous, (2009). Statics of Vegetable Production in Egypt. Ministry of Agriculture and Land Reclamation, Cairo.
Anonymous, (1996). Protected cultivation manual. UNDP- FAO- EGY/95/002.

Black, C.A. (1969). Methods of Soil Analysis. Amer. Soc. of Agron. Inc. Madison. USA.

Bonanno, A.R. and H.J. Mack. (1983). Water relations and growth of snap beans as influenced by differential irrigation. J. Am. Soc. Hort. Sci. 108: 837-844.

Campen, J.B. and G.P.A. Bot (2003). Determination of green-house-specific aspects of ventilation using three-dimensional computational fluid dynamics. Biosystem Engineering, 84(1): 69-77.

Cantliffe, D.J. (1977). Nitrogen fertilizer requirements of pickling cucumbers grown for onceover harvest II. Effect on yield and fresh quality. J. Amer. Soc. Hort. Sci. 102: 112-114.

Chapman, H.D. and F. Pratt. (1961). Methods of analysis for soils, Plants and Water. Univ. of Calif., USA.

Clough, G.H.; S.J. Locascio and S.M. Olson. (1992). Mineral concentration of yellow squash responds to irrigation method and fertilization management. J. Amer. Soc. Hort. Sci. 117: 725-729.

Donnatlli, M.; G. Bellocchi and L. Carlini. (2006). Sharing knowledge via software components: Models on reference evapotranspiration. Europ. J. Agronomy 24: 186-192.

Doorenbos, J. and W.O. Pruitt. (1977). Guidelines for Predicting Crop Water Reqiurements. Irrigation and Drainage Paper, No. 24. 144 pp. FAO, Rome.

El-Aidy, F.; A. El-zawely; N. Hassan; M. Elsawy. (2007). Effect of plastic tunnel size on production of cucumber in delta of Egypt. Applied Ecology and Environmental Research, 5(2): 11-24. 
El-Gizawy, A.M.; M.M.F. Abdalla; H.M. Gomaa and S.S. Mohammed. (1992). Effect of different shading level on tomato plants yield and fruit quality. Acta Hort. 323: 349-354.

El-Nemr, M.A. (2006). Effect of mulch types on soil environmental conditions and their effect on the growth and yield of cucumber plants. Journal of Applied Sciences Research 2(2): 67-73.

El-Shinawy, M.Z. (1997). Response of Cucumber Plants to Irrigation under Some Environmental Conditions. pp. 65-66. Ph.D. Thesis, Fac. Agric., Ain Shams Univ., Cairo, Egypt.

FAO. (1980). Soil and plant analysis. Soils Bulletin, 38: 2-250, FAO, Rome.

FAO. (1982). Crop Water Requirements Irrigation and Drainage. Paper No. 24, FAO, Rome, Italy.

Fonsecal, I.C.; A.E. Klar; R. Goto and C.S. Nevesl. (2003). Colored polyethylene soil covers and grafting effects on cucumber flowering and yield. Scientia Agricola, 60: 643-649.

Gaafer, S.A. and K.M. Refaie. (2006). Modeling water effects on growth and yield of melon cv. Reticulates. Egypt. J. of Appl. Sci. 21: 682693.

Hashem, F.A. (2007). Studies on Water Requirements and Nitrogen Fertilization for Cucumber under Protected Cultivation. p. 33. M.Sc. Thesis, Ain Shams University, Egypt.

Halim, O.; Y. Erdem and T. Erdem. (2003). Crop water stress index for watermelon. Scientia Horticulturae. 98: 121-130.

Iglesias, I. and S. Alegre. (2006). The effect of anti-hail nets on fruit protection, radiation, temperature, quality and profi tability of 'Mondial Gala' apples. J. of Applied Horticulture, 8(2): 91-100.

Jackson, M.L. (1967). Soil Chemical Analysis. Prentice-Hall. Inc. Englewood Cliffs, New Jersy. USA.

Janoudi, A.K. and I.E. Widders. (1993). Water deficits and fruiting affect carbon assimilation and allocation in cucumber plants, HortScience 28: 98-100.

Jifon, J.L. and J.P. Syvertsen. (2003). Kaolin particle film applications can increase photosynthesis and water use efficiency of 'Ruby red' grapefruit leaves. J. Amer. Soc. Hort. Sci. 128: 107-112.

Lorenzo, P.; M.C. Sanchez-Guerrero; E. Medrano; M.L. Garcia; I. Caparros; G. CoeIho, and M. Gimenez. (2004). Climate control in the summer season: a comparative study of external mobile shading and fog system. Acta Hort. 659: 189-194.

Lorenzo, P.; M.L. Garcia; M.C. SanchezGuerrero; E. Medrano; I. Caparros and M. Gimenez. (2006). Influence of Mobile Shading on Yield, Crop Transpiration and Water Use Efficiency. Acta Hort. 719: 471-478.

Marouelli, W.A. and W.L. Silva. (2005). Drip irrigation frequency for processing tomatoes during vegetative growth stage. Pes. Agropec. Brasil. 40: 661-666.

Nerson, H.; M. Edelstein; R. Berdugo and Y. Ankorion. (1997). Monopotassium phosphate as a phosphorus and potassium source for green-house winter grown cucumber and muskmelon. J. Plant Nutr., 20: 335-344.

Ngouajio, M.; G. Wang and R. Goldy, (2007). Withholding of drip irrigation between transplanting and flowering increases the yield of field-grown tomato under plastic mulch Agric. Water Management, 87: 285- 291.

Piper, C.S. (1950). Soil and Plant Analysis. Inter Science Publisher. Inc., New York, USA

Saleh, M.I. and K. Ozawa. (2006). Improvement of crop yield, soil moisture distribution and water use efficiency in sandy soils by clay application. Proc. of the Tenth International Water Technology Conference, Alexandria, Egypt, pp. 797-811.

Salman, S.K.; A.F. Abou-Hadid; I.M.J. Beltagy and A.S. Beltagy. (1992). Plastic house microclimate as affected by low tunnels and plastic mulch. Egyptian J. of Hort., 2: 111119.

Snedecor, G.W. and W.G. Cochran. (1981). Statistical Methods, Sixth Edition, lowa State Univ. Press, Ames. lowa, USA.

Wang, S. and F. Zhang. (2004). Effect of different water treatment on photosynthesis characteristics and leaf ultra structure of cucumber growing in solar green-house. Acta Hort. 633: 397-401.

Watanabe, F.S. and S.R. Olsen. (1965). Test of an ascorbic acid method for determining phosphorus in water and $\mathrm{Na} \mathrm{HCO} 3$ extracts from soil. Soil Sci. Soc. Amer. Proc. 29: 677678.

Yesim, E.A. and N. Yuksel. (2003). Yield response of watermelon to irrigation shortage. Scientia Horticulturae. 98: 365-383.

Zegbe-Dominguez, J.A.; M.H. Behboudian and B.E. Clothier. (2006). Responses of processing tomato to partial root zone drying at different phonological stages. Irrig. Sci. 24: 203-210. 